\title{
Antifungal potential of purified 3-(4- isopropylstyryl)-5-methylcyclohex-2-enone from marine actinobacteria Streptomyces albus A18
}

\section{Mizaeir Mehtha Abdul Kader ${ }^{1}$, Murugan Sambantham ${ }^{2}$ and Jothiprakasam Vinoth ${ }^{1,2}, *$}

${ }^{1}$ Thiagarajar College. Department of Zoology \& Microbiology. Madurai-625009. Tamil Nadu. India. *Email: vinodbio89@gmail.com.

${ }^{2}$ Annamalai University. Parangipettai-608 502. Tamil Nadu. India.

\begin{abstract}
Actinomycetes are known to produce potential secondary metabolites which comprise biological activity. The present work endeavor is to assess the fungicidal property of novel marine actinobacterial compound 3-(4-isopropylstyryl)-5methylcyclohex-2-enone extracted and isolated from Streptomyces albus AC18. The crude compound was loaded on silica gel column and eluted with chloroform - methanol - water. The purity of isolated compound were analyzed by TLC using chloroform and methanol as the solvent system and verified by GC-MS. The purified compound structure was established from infrared, ultraviolet, ${ }^{1} \mathrm{H}-\mathrm{NMR},{ }^{13} \mathrm{C}$-NMR and mass spectral data. The chemical shift assignments for the aliphatic compound from ${ }_{1}^{1} \mathrm{H}-\mathrm{NMR}$ corresponds to molecular formula as $\mathrm{C}_{18} \mathrm{H}_{22} \mathrm{O}$. The Bioassay-guided fraction leads to the isolation of compound, was identified as 3-(4-isopropylstyryl)-5-methylcyclohex-2-enone. Hence, this marine isolated $S$. albus AC18 actino-bacterial compound seem to be more efficient in its antifungal activity and acts as prominent reservoir for novel drug molecules en route for answering several fungal diseases.
\end{abstract}

Keywords: Streptomyces albus; Anti-fungi; TLC; GC-MS; NMR.
Received

January 27, 2020

Accepted

August 22, 2020

Released

August 31, 2020

Full Text Article

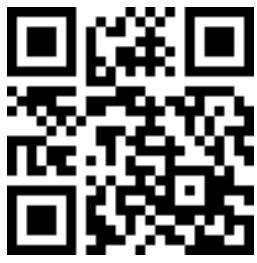

ORCID

(D) 0000-0001-7042-8828 Mizaeir Mehtha Abdul Kader

(1) 0000-0003-2769-4017 Murugan Sambantham

(1) 0000-0002-7706-1712 Jothiprakasam Vinoth

\section{Introduction}

Actinomycetes are most economically and biotechnologically valuable prokaryotes (Saravanakumar et al., 2010), possess capabilities in production of antibiotics and other compounds of biotechnological importance (Jain and Jain, 2005). Moreover they are 
potential producers of antifungal compounds used as commercial antibiotics such as Natamycin "polyene" produced by Streptomyces lydicus AZ-55 (Atta et al., 2015). Streptomyces sp DPTB16 strain produced antifungal compound named 4' phenyl-1napthyl-phenyl acetamide showing broad spectrum activity, finds application in managing human infectious fungal disease (Dhanasekaran et al., 2008).

Keeping in mind, the current investigation was attempted in isolation of potential antifungal compound 3-(4-isopropylstyryl)-5-methylcyclohex-2-enone from Streptomyces albus AC18 and to characterize its effect against fungal pathogens.

\section{Materials and methods}

AC18

\section{Isolation of antifungal compound producing marine actinobacterial strain}

The sediments were collected from Pichavaram mangroves marine zone (Latitude $11^{\circ} 25^{\prime} \mathrm{N}$ and Longitude $79^{\circ} 47^{\prime} \mathrm{E}$ ) and transferred to the laboratory, stored at $4^{\circ} \mathrm{C}$. The collected sediments were land air dried aseptically. The serially diluted samples were plated on starch casein agar supplemented with $75 \mu \mathrm{g} / \mathrm{mL}$ of nalidixic acid and $80 \mu \mathrm{g} / \mathrm{mL}$ of cycloheximide (Himedia, Mumbai, India) prior to minimize bacterial and fungal growth and incubated at $28^{\circ} \mathrm{C}$ for 8 days (Kim et al., 1994). After 8 days, morphologically different actinobacterial colonies were sub-cultured on ISP 2 medium slants and were maintained at $4{ }^{\circ} \mathrm{C}$ for further studies.

\section{Screening of marine actinobacterial strain AC18 for antifungal activity}

The isolated actinomycetes were screened for antifungal activity against Mucor sp fungal pathogen in cross streak plate method on Kuster's agar, incubated at $28^{\circ} \mathrm{C} \pm 2{ }^{\circ} \mathrm{C}$ for 3 to 4 days (Kim et al., 1994). After observing a good ribbon like growth of the actinomycetes, the fungal pathogens were streaked at right angle near the original streak of actinomycetes and incubated at $28^{\circ} \mathrm{C} \pm 2{ }^{\circ} \mathrm{C}$ for $48 \mathrm{~h}$. The maximum clear zone colonies were considered as potential strain for actinobacterial compound production and characterization studies. As well control plates were also maintained to assess normal pathogenic fungal growth.

For second screening, the mature spores of $S$. albus AC18 strain were inoculated in $100 \mathrm{~mL}$ of fermentation medium containing Casein enzymic hydrolysate - 20g/L, Cystine $0.5 \mathrm{~g} / \mathrm{L}$, Sodium chloride $-5 \mathrm{~g} / \mathrm{L}$, Sodium sulphate $-0.5 \mathrm{~g} / \mathrm{L}$, Phenol red $-0.017 \mathrm{~g} / \mathrm{L}$, Agar $3.5 \mathrm{~g} / \mathrm{L}$, Final pH $-7.5 \pm 0.1$ and incubated on $30^{\circ} \mathrm{C}$ for 8 days at $200 \mathrm{rpm}$. The fermented broth was centrifuged at $10,000 \mathrm{xg}\left(4^{\circ} \mathrm{C}\right)$ for $20 \mathrm{~min}$ and supernatant was filtered through $0.45 \mu \mathrm{m}$ pore size membrane filter used for further antifungal activity (Ruan, 1977). To check antifungal spectrum, pathogenic fungus were cultured on Sabouraud dextrose broth at $27{ }^{\circ} \mathrm{C}$ for $24 \mathrm{~h}$ and consecutively swapped on Muller Hinten agar plates. Besides, the wells prepared at the plate's center were filled with $100 \mu \mathrm{L}$ of fermented medium and incubated at $27^{\circ} \mathrm{C}$ for 3 days and the diameter of inhibition zone was observed.

\section{Taxonomic identification of actinobacterial strain AC 18}

The potential antifungal compound producing actinobacterial strain AC18 were identified based on morphological, biochemical and chemo taxonomical characteristics (analysis of cell wall sugar and cell wall amino acid analysis). Further utilization of carbon sources such as starch, dextrose, fructose, maltose, and mannitol and nitrogen sources namely D-alanine, L-arginine, and L-tyrosine were tested on Kuster's agar.

\section{Molecular identification and phylogenetic analysis}

DNA was isolated from the pure culture of isolate as per protocol described by (Kieser et al., 2000). In brief actinomycetes spores were centrifuged at 13,000 $\times \mathrm{g}$ for $5 \mathrm{~min}$ 
and $1 \mu \mathrm{L}$ of supernatant was used as template for amplification along with ITS 5 primer pair (White et al., 1990). The PCR conditions were as follows: initial denaturation at $95^{\circ} \mathrm{C}$ for $15 \mathrm{~min}$; followed by 45 cycles of denaturation at $94{ }^{\circ} \mathrm{C}$ for $20 \mathrm{~s}$, annealing at $55^{\circ} \mathrm{C}$ for $1 \mathrm{~min}$, extension at $72{ }^{\circ} \mathrm{C}$ for $50 \mathrm{~s}$; and final extension at $72{ }^{\circ} \mathrm{C}$ for $10 \mathrm{~min}$. PCR amplification was carried out using action specific forward primer, 27F (5'-AGAGTTTGATCCTGGCTCAG-3'), used with reverse primers 1492R (5'-GGGTTACCTTGTTACGACTT-3'). The DNA sequences obtained from both strands were read on an ABI PRISM 377 DNA sequence. The homology of the sequences were analyzed using BLAST algorithm (http://www.ncbi.nlm.nih.gov) and were aligned with references taxa along with their GenBank accession numbers using Clustal W implemented in MEGA4 software (Tamura et al., 2007)

\section{Purification and characterization of antifungal compound}

Thin layer chromatography. TLC was performed to obtain partially purified compound. Crude sample were placed on the TLC plate as a single line and the chromatogram was made with the solvent system (Chloroform:Methanol). After separation, the active spot band was scrapped, mixed with methanol and centrifuged at $3,000 \mathrm{xg}$ for $15 \mathrm{~min}$. Followed by, supernatant was collected in a pre-weighed vial and kept under evaporation. Further, the partially purified compound obtained through TLC was tested for its antifungal activity against pathogenic fungi by well diffusion method.

FT-IR analysis. The partially purified sample was subjected to FT-IR spectroscopy to analyze functional groups such as sulphate, amino carboxyl and hydroxyl groups, (Perkin-Elmer-FT-IR-instrument). Briefly, the sample was mixed with 1,000 mg of dried KBR pellet of $3 \mathrm{~mm}$ diameter and $1 \mathrm{~mm}$ thickness. Absorbance spectra were recorded using Nicolet Avatus 360FTIR spectrometer equipped with KBR beam splitter and an air cooled DTGS detector. The absorption of light intensity of the peaks was calculated using the base line method; the frequencies for all sharp bands were accurate to $0.01 \mathrm{~cm}^{-1}$.

GC-MS analysis. Consecutively to identify the compound, the sample was dissolved in methanol and subjected to GC-MS (Agilent technologies $6890 \mathrm{~N}$ network GC system for gas chromatography). The analysis conditions were $20 \mathrm{~min}$ at $100{ }^{\circ} \mathrm{C}, 3 \mathrm{~min}$ at $235{ }^{\circ} \mathrm{C}$ for column temperature, $240{ }^{\circ} \mathrm{C}$ for injector temperature, helium was used as carrier gas and split ratio was $3: 8$. The sample $(1 \mu \mathrm{L})$ was evaporated in a split less injector at $300^{\circ} \mathrm{C}$ with the run time of $22 \mathrm{~min}$. The component was identified through gas chromatography coupled with mass spectrometry. Further, the compound was identified through interpretation on mass spectrum using National Institute Standard and Technology (NIST) library search database which contained more than 62,000 drugs formulation. Hence mass spectrum of the unknown component was compared with the spectrum known components stored in the NIST08 and Wiley 08 library.

Nuclear magnetic resonance ( ${ }^{13} \mathrm{C}$ and ${ }^{1} \mathrm{H}$ NMR). NMR measurements were done at ${ }^{1} \mathrm{H}$ and ${ }^{13} \mathrm{C}$ spectra and recorded at $300 \mathrm{~K}$ on Bruker Advance DRX300, DPX400, DRX600 and DMX600 NMR spectrometers. Using standard Bruker software all 1D and 2D spectra was obtained. 3D structure of the pure compound was predicted based on NMR spectral data model using Chem3D Ultra software (Version 8). The samples were dissolved in $\mathrm{CDCl}_{3}$ solvents and the residual solvent signals were used as internal standards (reference signal). The observed chemical shift ( $\alpha$ ) values are given in ppm and the coupling constant (J) in HZ. 


\section{Results}

\section{actinobacteria}

Isolation, identification of antifungal compound producing marine

A total of 22 actinobacterial strains were isolated from Pichavaram marine sediments and screened for its antifungal activity. Among them, the strain AC18 exhibited wide spectrum of antifungal activity against fungal pathogen. The vegetative mycelia of the strain AC18 grew abundantly on both synthetic and complex media, the aerial mycelia grew on International Streptomyces Project-7 medium (ISP-7),shown in. The SEM examination revealed the spore chains orientation owning warty surface. Neither both sclerotic granules and sporangia nor flagellated spores were observed. Chemo taxonomical analysis revealed that cell wall hydrolysate contains LL-diaminopimelic acid (LL-DAP) and the sugar pattern was not detected.

Table 1. Morphological and biochemical characteristics of actinomyces isolates.

\begin{tabular}{|c|c|}
\hline Test & Growth characteristics \\
\hline \multicolumn{2}{|l|}{ Morphological characteristics } \\
\hline Spore morphology & Orientation \\
\hline Colour of aerial mycelium & Grey \\
\hline Colour of substrate mycelium & Coffee brown \\
\hline Spore mass & Grey \\
\hline \multicolumn{2}{|l|}{ Biochemical characteristics } \\
\hline Indole production & Negative \\
\hline Methyl red & Negative \\
\hline Voges proskauer & Negative \\
\hline Citrate utilization & Positive \\
\hline H2S production & Negative \\
\hline Nitrate reduction & Negative \\
\hline Catalase & Positive \\
\hline Oxidase & Negative \\
\hline Melanin production & Negative \\
\hline Starch hydrolysis & Positive \\
\hline Gelatin hydrolysis & Positive \\
\hline Lipid hydrolysis & Positive \\
\hline Casein hydrolysis & Positive \\
\hline Haemolysis & Negative \\
\hline Triple Sugar iron & Alkaline butt/Alkaline slant \\
\hline \multicolumn{2}{|l|}{ Chemotaxonomic characters } \\
\hline Whole cell sugar analysis & Negative \\
\hline Cell wall amino acid analysis & LL-DAP \\
\hline \multicolumn{2}{|l|}{ Carbon source utilization } \\
\hline Starch & Highly positive \\
\hline Dextrose & Highly positive \\
\hline Fructose & Positive \\
\hline Maltose & Highly positive \\
\hline Mannitol & Highly positive \\
\hline \multicolumn{2}{|l|}{ Nitrogen utilization } \\
\hline D-alanine & Highly positive \\
\hline L-arginine & Highly positive \\
\hline L-phenylalanine & Highly positive \\
\hline L-tyrosine & Highly positive \\
\hline
\end{tabular}


The morphological and biochemical investigations of isolate AC18 were presented in Table 1. The isolate AC 18 have utilized all carbon and nitrogen sources. The urease and catalase were shown positive, melanin production and citrate utilization were shown negative. The cultural characteristics of AC18 strain revealed that the growth depends on available nutrients present in the medium and the physical conditions. Upon the growth of the isolate AC18 on various media, Tyrosine agar (ISP-7) was observed to be a superlative medium for maximal growth (Table 2).

Table 2. Maximal growth on different medium.

\begin{tabular}{|l|c|c|c|}
\hline Name of the medium & $\begin{array}{c}\text { Aerial } \\
\text { mycelium }\end{array}$ & $\begin{array}{c}\text { Substrate } \\
\text { mycelium }\end{array}$ & Pigmentation \\
\hline Malt extract and yeast extract Agar (ISP-2) & Dull white & Dark yellow & Nil \\
\hline Oat meal agar (ISP-3) & Grey & Red & Dark pink \\
\hline Inorganic Salt Starch agar (ISP-4) & Grey & Yellowish green & Nil \\
\hline Glycerol asparagine's agar & Grey & Light Grey & Nil \\
\hline Tyrosine agar (ISP-7) & Grey & Brown & Nil \\
\hline Kuster's agar & Grey & Dark yellow & Pale pink \\
\hline Actinomycetes isolation agar & Grey & Brown & Nil \\
\hline Starch casein agar & Grey & Brown & Nil \\
\hline
\end{tabular}

Based on the International Key's (Buchanan and Gibbons, 1974) and numerical taxonomy of Streptomyces species program (Hensyl, 1994) the AC18 strain seemed to be closely related to Streptomyces albus. Further, the molecular phylogeny of strain AC18 through $16 \mathrm{~S}$ rDNA sequence and phylogenetic tree analysis confirmed that it has exhibited 99\% homology with Streptomyces albus.

\section{Production and purification of the antifungal compound from S. albus AC18}

For the production of antifungal compound, fermentation was carried out in antibiotic production medium for 7 days at $27^{\circ} \mathrm{C}$ followed by filtration through centrifugation at $5,000 \mathrm{xg}$ for $15 \mathrm{~min}$ at $4^{\circ} \mathrm{C}$. After fermentation, the cell free supernatant was mixed with equal volume of ethyl acetate, and the solvent layer was separated using a separating funnel and concentrated in rotary evaporator at $80^{\circ} \mathrm{C}$. Among the five fractions obtained through thin layer chromatography (TLC), fraction III exhibited wide spectrum antifungal activity. For the analysis of respective fraction preparative thin layer chromatography (TLC) was performed which yielded a single spot with Rf value of 0.83 .

\section{Characterization of the antifungal compound}

FT-IR spectrum depict that the strong absorption observed at $1,666 \mathrm{~cm}^{-1}$ was due to $\mathrm{C}=0$ stretching frequency and the peaks obtained at 2,870, 2,745 and $2,959 \mathrm{~cm}^{-1}$ were due to the presence of aliphatic $\mathrm{C}-\mathrm{H}$ stretching and aromatic ring $\mathrm{C}-\mathrm{H}$ stretching, respectively (Figure 1). Further, GC-MS analysis confirmed that the molecular weight of the purified compound was about $254 \mathrm{MW}$ which were presented as 253 due to a proton loss (Figure 2). 


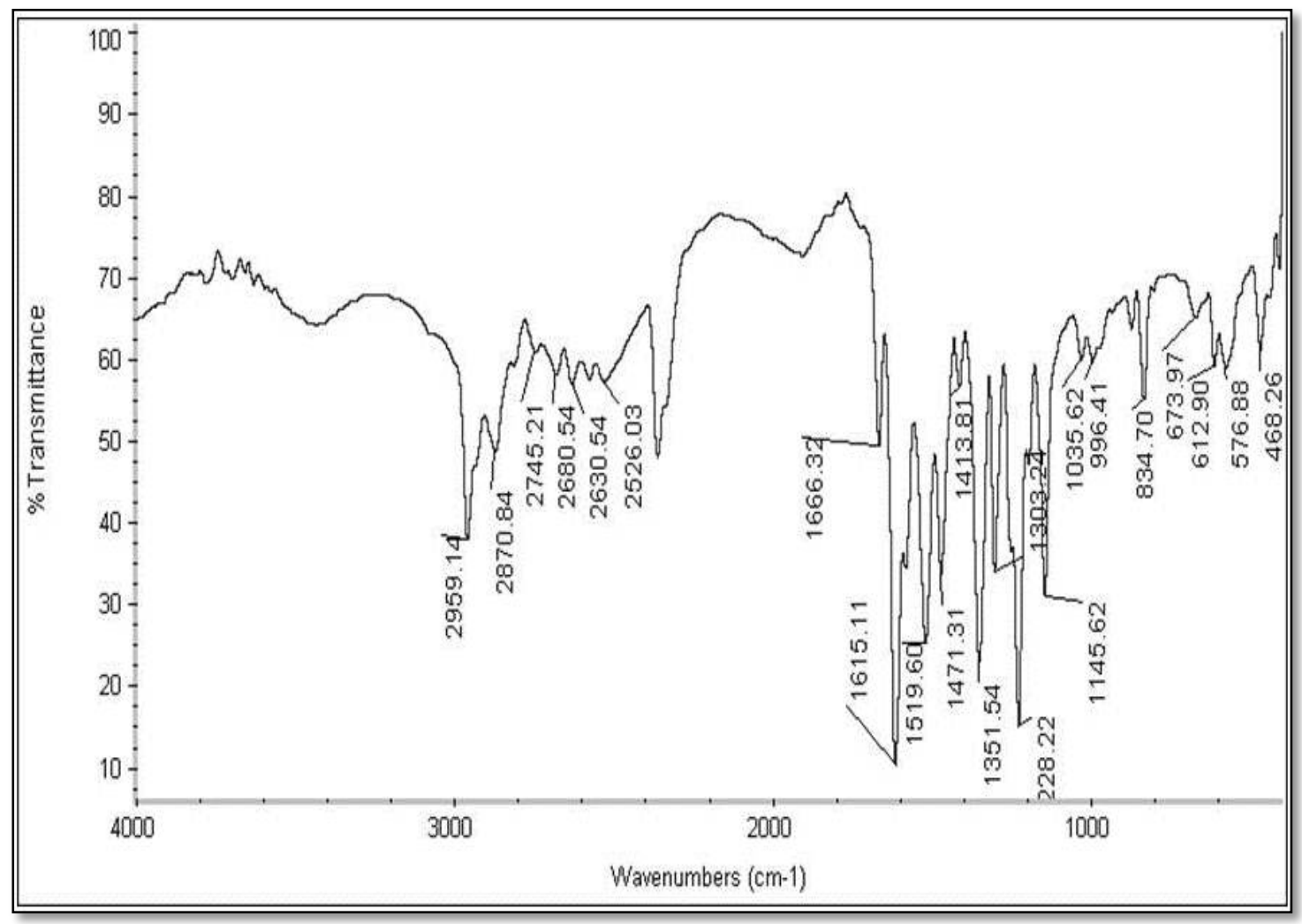

Figure 1. FT-IR spectrum of the antifungal compound form Streptomyces albus AC18.

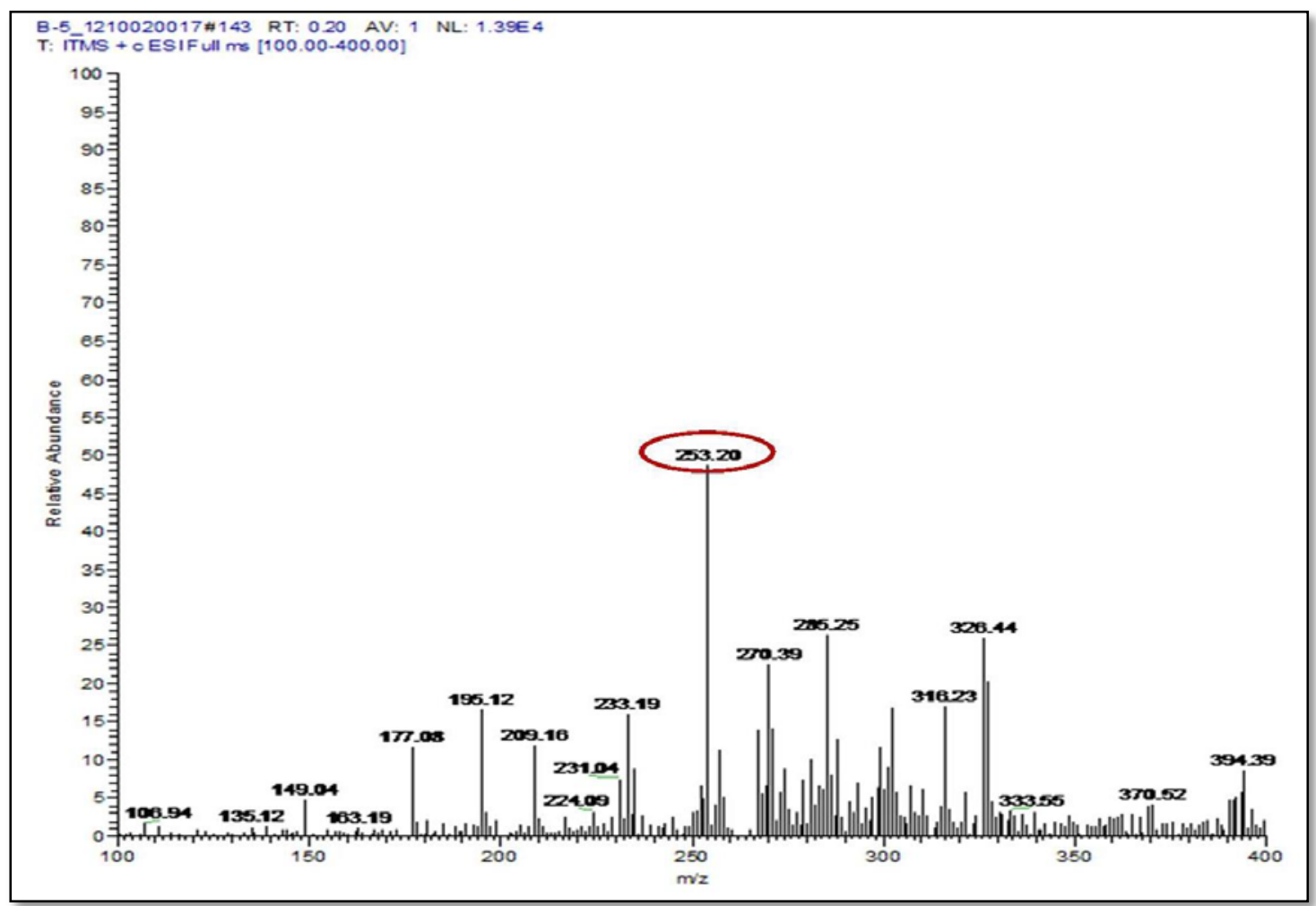

Figure 2. Mass spectrophotometry of the purified compound from Streptomyces albus AC18 with the molecular weight of 253. 
Based on ${ }^{1} \mathrm{H}-\mathrm{NMR}$ and ${ }^{13} \mathrm{C}-\mathrm{NMR}$ studies, the purified antifungal compound from Streptomyces albus AC18 was identified as 3-(4-isopropylstyryl)-5-methylcyclohex-2enone having molecular formula of $\mathrm{C}_{18} \mathrm{H}_{22} \mathrm{O}$ and the molecular weight was about 253.20 MW. Structure of the purified antifungal compound 3-(4-isopropylstyryl)-5methylcyclohex-2-enone produced by Streptomyces albus AC18 (Figure 3). 3D structure of the pure compound of 3-(4-isopropylstyryl)-5-methylcyclohex-2-enone (Figure 4).

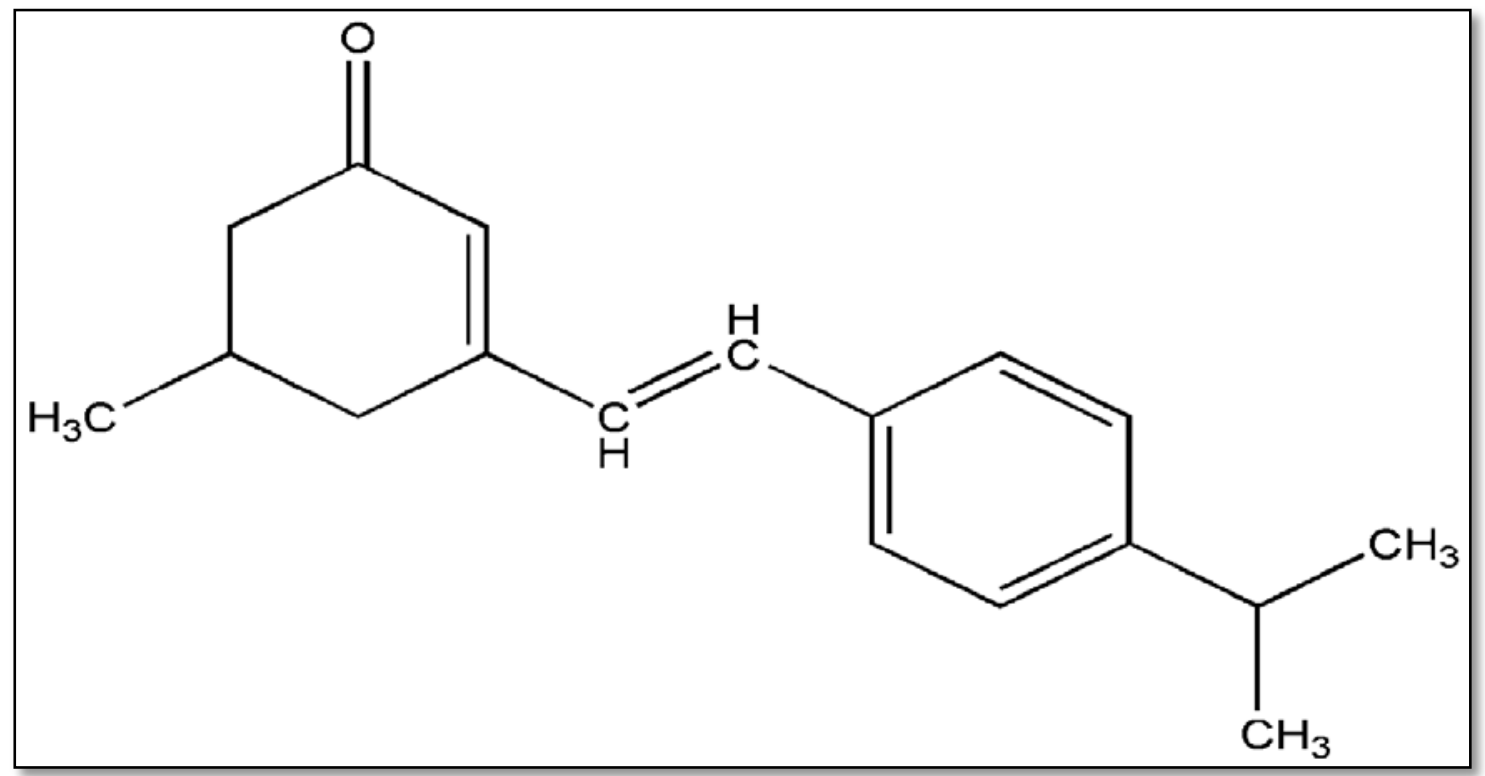

Figure 3. Structure of the purified antifungal compound 3-(4-isopropylstyryl)-5-methylcyclohex-2enone.

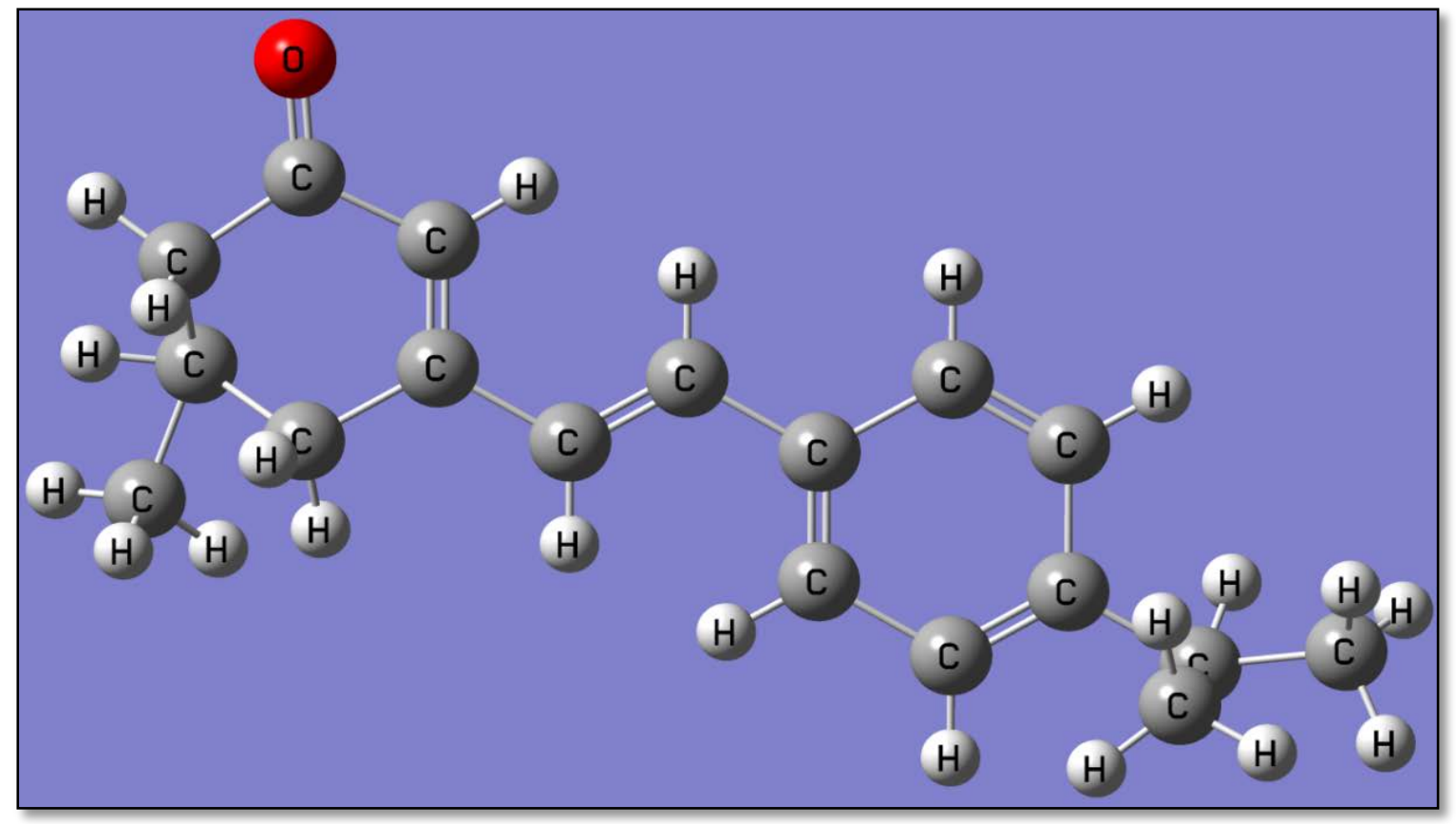

Figure 4. 3D structure of the pure compound of 3-(4-isopropylstyryl)-5 methylcyclohex-2-enone. 


\section{Discussion and conclusion}

Fungal infections has been prominent in recent years and become a significant medical problem, due to increased immune-compromised patients with innate or acquired immune-deficiencies (Jarvis, 1995). Such increased frequency of multi-resistant pathogenic fungi have created demand in pharmaceutical industries in screening of new antibiotics with a broad spectrum of activity, which resist the inactivation processes exploited by microbial enzymes (Motta et al., 2004). Nevertheless several reports on control of secondary metabolite production by actinobacteria (Motta et al., 2004), pharmacological compounds production from marine actinomycetes with antibiotic and antitumor properties (Suthindhiran and Kannabiran 2004) are available. Hence search for active secondary metabolites produced by environmental isolates using poorly explored microorganisms, could provide a new source for novel bioactive compounds discovery.

In present study, a total of twenty-two actinobacterial strains were isolated from Pichavaram marine sediments and strain AC18 was found exhibiting wide spectrum antifungal activities. The maximum antifungal compound biosynthesis can be recorded at pH 7.0 (Atta, 1999); temperature $35^{\circ} \mathrm{C}$ (Kunnari et al., 1997; Atta, 1999); glucose was found to be best carbon source (Hoshino ei al., 2004) $\mathrm{KNO}_{3}$ seem to be best nitrogen source (Hosokawa et al., 1996; Atta, 1999; Khalifa, 2008). The molecular taxonomy of actinobacterial strain based on $16 \mathrm{~S} r$ DNA sequencing and the phylogenetic tree (diagram) revealed the identification of Streptomyces albus strain.

In this work, the antifungal compound extracted from culture supernatant was tested against fungal pathogens. The antifungal activity percentage was found higher when compared with the activity of Moroccan soil Streptomyces sp (Barakate et al., 2002). Moreover, strain AC18 antifungal activity was relatively different from other studies exhibiting 16\% in soil of Turkey (Oskay et al., 2004); 53\%-61\% in Algerian soil (Sabaou et al., 1998) and 44.5\% in soils of South-Eastern Serbia (Ilic et al., 2005, 2007). Whereas, similar inhibitory pattern was demonstrated by ethyl acetate extracts of marine Streptomyces sp. RM17 and RM42 (Remya and Vijayakumar, 2008) and marine Streptomyces isolates from the Andaman Coast of Bay of Bengal (Peela et al., 2005). The broad antifungal spectrum exhibited by strain AC18 highlighted its potential and proposed to be important candidate for antibiotics. Hence, the present study provides first hand information on antifungal agent production from Streptomyces albus against fungal pathogens. The identification of antifungal compound produced by strain AC18 was investigated through TLC, PTLC, FT-IR, GC-MS and NMR analysis. The results of TLC analysis confirmed the presence of single compound with Rf value of 0.55 . Further, the purified compound was allowed to pass through silica gel column and eluted with chloroform and methanol (1:9 ratio); the Rf value of most active fraction against shrimp fouling fungus was about 0.83 . Similarly, many workers purified the antifungal compounds through silica gel column and eluted with solvent comprised of various ratios of chloroform and methanol (Criswell et al., 2006; Sekiguchi et al., 2007).

The Numerical Magnetic Resonance (NMR) based studies revealed that the antifungal compound extracted and purified from Streptomyces albus AC18 was identified as 3-(4-isopropylstyryl)-5-methylcyclohex-2-enone $\left(\mathrm{C}_{18} \mathrm{H}_{22} \mathrm{O}\right)$ having the molecular mass of 253.20. The elemental analysis studies confirmed the ${ }^{1} \mathrm{H}-\mathrm{NMR}$ and ${ }^{13} \mathrm{C}-\mathrm{NMR}$ spectrum of 3-(4-isopropylstyryl)-5-methylcyclohex-2-enone, the singlet appeared at $0.92 \mathrm{ppm}$ was due to methyl proton attached to C5 carbon. The potential antifungal compound named 4'phenyl 1-napthyl phenyl acetamide from Streptomyces sp. DPTB16 were identified and reported by (Dhanasekaran et al., 2008). However, Hwang et al. (2001) reported that, the phenyl acetic acid and sodium phenyl acetate are potential compounds obtained from Streptomyces humidus. 
The present investigation reveals the importance of obtaining novel antifungal compound from Streptomyces albus AC18 against fungal pathogens. As a result the antifungal compound 3-(4-isopropylstyryl)-5-methylcyclohex-2-enone $\left(\mathrm{C}_{18} \mathrm{H}_{22} \mathrm{O}\right)$ produced by putative Streptomyces albus AC18 isolated from marine sediments might be used as novel antibiotics against fungal infections.

\section{Acknowledgements}

The authors are grateful thanks Prof. K. Kathiresan, Former Dean and Director, CAS in Marine biology, Faculty of Marine Sciences, Annamalai University for giving facilities and encouragement and also we thank to the Ministry of Human Resource and Development (MHRD), Government of India, New Delhi for providing financial support during the study period. The author hearty thanks to department of zoology and microbiology for giving facilites.

\section{Conflict of interest}

The authors declare that they have no conflicts of interest.

\section{References}

Atta, H. M. Application of biotechnology in search for antibiotics from environmental pollutants under solid state fermentation conditions. Cairo, Egypt: Faculty of Science, Al-Azhar University, 1999. (Ph.D. thesis).

Atta, H. M.; El-Sayed, A. S.; El-Desoukey, M. A.; Hassan, M.; El-Gazar, M. Biochemical studies on the Natamycin antibiotic produced by Streptomyces lydicus: Fermentation, extraction and biological activities. Journal of Saudi Chemical Society, v. 19, p. 360-371, 2015. https://doi.org/10.1016/j.jscs.2012.04.001

Barakate, M.; Ouhdouch, Y.; Oufdou, K.; Beaulieu, C. Characterization of rhziosphere soil streptomycetes from Moroccan habitats and their antimicrobial activities. World Journal of Microbiology and Biotechnology, v. 18, p. 49-54, 2002. https://doi.org/ 10.1023/A:1013966407890

Criswell, D.; Tobiason, V. L.; Lodmell, J. S.; Samuels, D. S. Mutations conferring aminoglycoside and spectinomycin resistance in Borrelia burgdorferi. Antimicrobial Agents and Chemotherapy, v. 50, p. 445-452, 2006. https://doi.org/10.1128/AAC.50.2.445452.2006

Dhanasekaran, D.; Thajuddin, N.; Panneerselvam, A. Antifungal compound: 4' phenyl-1napthyl-phenyl acetamide from Streptomyces sp. DPTB16. Facta Universitatis: Series Medicine and Biology, v. 15, p. 7-12, 2008.

Hoshino, Y.; Mukai, A.; Yazawa, K.; Uno, J.; Ando, A. Transvalencin A, a thiazolidine zinc complex antibiotic produced by a clinical isolate of Nocardia transvalensis. II. Structure elucidation. The Journal of Antibiotics, v. 57, p. 803-807, 2004. https://doi.org/10.7164/ antibiotics.57.803

Hosokawa, N.; Naganawa, H.; Hamada, M.; Takeuchi, T.; Ikeno, S.; Hori, M. Hydroxymycotrienins $\mathrm{A}$ and $\mathrm{B}$, new ansamycin group antibiotics. The Journal of Antibiotics, v. 49, p. 425-431, 1996. https://doi.org/10.7164/antibiotics.49.425 
Hwang, B. K.; Lim, S. W.; Kim, B. S.; Lee, J. Y.; Moon, S. S. Isolation and in vivo and in vitro antifungal activity of phenyl acetic acid and sodium phenyl acetate from Streptomyces humidus. Applied and Environmental Microbiology, v. 67, p. 3739-3745, 2001. https://doi.org/10.1128/aem.67.8.3739-3745.2001

Ilic, S. B.; Konstantinovic, S. S.; Todorovic, Z. B. Uv/vis analysis and antimicrobial activity of Streptomyces isolates. Facta Universitatis: Series Medicine and Biology, v. 12, p. 44-46, 2005.

Ilic, S. B.; Konstantinovic, S. S.; Todorovic, Z. B.; Lazic, M. L.; Veljkovic, V. B.; Jokovic, N.; Radovanovic, B. C. Characterization and antimicrobial activity of the bioactive metabolites in Streptomyces isolates. Microbiology, v. 76, p. 421-428, 2007. https://doi.org/10.1134/ S0026261707040066

Jain, P. K.; Jain, P. C. Production of heptaene antifungal antibiotic by Streptomyces purpeofuscus CM 1261. Indian Journal of Experimental Biology, v. 43, p. 342-345, 2005.

Jarvis, W. R. Epidemiology of nosocomial fungal infections, with emphasis on Candida species. Clinical Infectious Diseases, v. 20, p. 1526-1530, 1995. https://doi.org/ 10.1093/clinids/20.6.1526

Khalifa, M. A. Bioprocess development for the biosynthesis of bioactive compounds from microbial origin. Cairo, Egypt: Faculty of Science, Al-Azhar University, 2008. (M. Sc. thesis).

Kieser, T.; Bibb, M. J.; Buttner, M. J.; Chater, K. F.; Hopwood, D. A. Practical Streptomyces genetics. Norwich: The John Innes Foundation, 2000.

Kim, C. M.; Lec, K. H.; Kwon, O. S.; Shimazu, A.; Yoo, I. D. Selective isolation of actinomycetes by physical pre-treatment of soil sample. Korean Journal of Applied Microbiology and Biotechnology, v. 22, p. 222-225, 1994.

Kunnari, T.; Tuikkanen, J.; Hautala, A.; Hakala, J.; Ylihonko, K.; Mantsala, P. Isolation and characterization of 8-demethoxysteffimycins and generation of 2,8-demethoxy steffimycins in Streptomyces steffisburgensis by the nogalamycin biosynthesis genes. The Journal of Antibiotics, v. 50, p. 496-501, 1997. https://doi.org/10.7164/ antibiotics.50.496

Motta, L. S.; Silva, W. S.; Oliveira, D. M.; Souza, W.; Machado, E. A. A new model for proton pumping in animal cells: The role of pyrophosphate. Insect Biochemistry and Molecular Biology, v. 34, p. 19-27, 2004. https://doi.org/10.1016/j.ibmb.2003.07.002

Oskay, M.; Tamer, A. U.; Azeri, C. Antibacterial activity of some actinomycetes isolated from farming soils of Turkey. African Journal of Biotechnology, v. 3, p. 441-446, 2004. https://doi.org/10.5897/AJB2004.000-2087

Peela, S.; Kurada, B.; Terli, R. Studies on antagonistic marine actinomycetes from the Bay of Bengal. Visakhapatnam, India: Department of biotechnology, College of Science and Technology, 2005.

Remya, M.; Vijayakumar, R. Isolation and characterization of marine antagonistic Actinomycetes from West Coast of India. Facta Universitatis: Series Medicine and Biology, v. 15, p. 13-19, 2008.

Ruan, J. S. The basis of taxonomy of Actinomycetes. Beijing: The Chinese Academic Press, 1977. 
Sabaou, N.; Boudjella, H.; Bennadji, A.; Mostefaoui, A.; Zitouni A.; Lamari, L.; Bennadji, H.; Lefebvre, G.; Germain, P. Les sols des oasis du Sahara Algerien, source d'actinomycètes rares producteurs d'antibiotiques. Secheresse, v. 9, p. 147-153, 1998.

Saravanakumar, R.; Syed Moomeen, H.; Ronald J.; Kannan, M. Control of fish bacterial pathogens by antagonistic marine Actinomycetes isolated from Gulf of Mannar Coast. Word Journal of Fish and Marine Sciences, v. 2, p. 275-279, 2010.

Sekiguchi, M.; Shiraish, N.; Kobinata, K.; Kudo, T.; Yamaguchi, I. RS-22A, B and C: New macrolide antibiotics from Streptomyces violaceus niger. I. Taxonomy, fermentation, isolation and biological activities. The Journal of Antibiotics, v. 48, p. 289-292, 2007. https://doi.org/10.7164/antibiotics.48.289

Sivakumar, K.; Sahu, M. K.; Thangaradjou, I.; Kannan, L. Research on marine Actinobacteria in India. Indian Jounal of Microbiology, v. 47, p. 186-196, 2007. https://doi.org/ 10.1007/s12088-007-0039-1

Suthindhiran, K.; Kannabiran, K. Cytotoxic and antimicrobial potential of actinomycete species Saccharopolyspora salina VITSDK4 isolated from the Bay of Bengal Coast of India. American Journal of Infectious Diseases, v. 5, p. 90-98, 2004. https://doi.org/ 10.3844/ajidsp.2009.90.98

Tamura, K.; Dudley, J.; Nei, M.; Kumar, S. MEGA4: Molecular evolutionary genetics analysis (MEGA) software version 4.0. Molecular Biology and Evolution, v. 24, p. 1596-1599, 2007. https://doi.org/10.1093/molbev/msm092

White, T. J.; Bruns, T.; Lee, S.; Taylor, J. W. Amplification and direct sequencing of fungal ribosomal RNA genes for phylogenetics. In: Innis, M. A.; Gellfand, D. H.; Sninsky, J. J.; White, T. J. (Eds.). PCR protocols: Guide to methods and amplifications. New York: Academic Press, 1990. p. 315-322.

License information: This is an open-access article distributed under the terms of the Creative Commons Attribution License, which permits unrestricted use, distribution, and reproduction in any medium, provided the original work is properly cited. 